\title{
Is the rib hump (thoracic/surface deformity) always in agreement with the Cobb angle (spinal/radiological deformity)? A study in school-screening referrals, with aetiological implications Theodoros B Grivas*, Elias Vasiliadis, Olga Savvidou, Spiros Dangas, Georgios Triantafyllopoulos and Marinos Malakasis
}

\author{
Address: Orthopaedic Department, "Thriasio" General Hospital, G. Gennimata Av. 19600, Magoula, Attica, Greece \\ Email: Theodoros B Grivas* - grivastb@panafonet.gr \\ * Corresponding author
}

from 4th International Conference on Conservative Management of Spinal Deformities Boston, MA, USA. 13-16 May 2007

Published: 12 October 2007

Scoliosis 2007, 2(SuppI I):S30 doi:I0.II86/I748-7I6I-2-SI-S30

This abstract is available from: http://www.scoliosisjournal.com/content/2/SI/S30

(c) 2007 Grivas et al; licensee BioMed Central Ltd.

\section{Objective}

A discrepancy between scoliometer readings [1] and Cobb angle is observed in some younger children from school screening to the scoliosis clinic. The aim of this report is to assess the effect of age on the concordance of the surface and the radiological deformity in patients with adolescent idiopathic scoliosis (AIS) and to discuss the aetiological implications of this phenomenon.

\section{Study design}

A radiological study was conducted in order to determine the influence of age in the relationship between the deformity of the thorax (rib hump) and the deformity of the spine (Cobb angle) in scoliotics. Eighty-three girls (mean age 13.39 years, range $7-18$ years), referred to hospital from a school screening program were assessed. All satisfied the inclusion criterion for referral which was the presence of a thoracic deformity (hump) expressed as Angle of Trunk Rotation (ATR) [1] of greater than or equal to seven degrees. The spinal deformity was assessed radiographically by reading the Cobb angle from the posteroanterior spinal radiographs (SR). The surface/thoracic-rib/ hump deformity was quantified, from the lateral SR, assessing the "rib-index" [2]. The data were statistically analysed using SPSS for Windows, v12 http:// www.spss.com.

\section{Results}

The girls were divided into five groups: 1) straight spines, $(\mathrm{n}=15) ; 2$ ) spinal curvature with Cobb angle $<10$ degrees $(\mathrm{n}=7) ; 3)$ thoracic $(\mathrm{n}=30) ; 4)$ thoracolumbar $(\mathrm{n}=10)$; and 5) lumbar curves $10-20$ degrees $(n=21)$ respectively. When regressing linearly the dependent variable "CobbThoracic" with the independent (predictor) "rib-index" without the effect of the variable "age" there is no statistical significance $(\mathrm{SS})(\mathrm{p}<.227)$ and it is statistically significant when the effect of the (predictor) variable "age", (p $<0.05)$ is included. The same was found for the thoracolumbar spine, $(\mathrm{p}<0.02)$, but not for the lumbar spine ( $\mathrm{p}$ $<0.6)$.

\section{Conclusion}

The thoracic/surface deformity expressed as the rib hump and the spinal/radiological deformity expressed as the Cobb angle, were correlated in AIS patients, and formulas were created to predict Cobb angle from scoliometer readings. Our results show that the above approach is inaccurate as age influences the agreement of these two deformities. In younger children the concordance of the surface and radiological deformity is weak and it becomes stronger by the age. The aetiological implications are that the thoracic cage deformation precedes and then the deformation of the central axis, namely the spine, follows. 


\section{References}

I. Bunnell WP: An objective criterion for scoliosis screening. J Bone Joint Surg 1984, 66A: 1381-1387.

2. Grivas TB, Dangas S, Polyzois BD, Samelis P: The Double Rib Contour Sign (DRCS) in lateral spinal radiographs: aetiologic implications for scoliosis. Stud Health Technol Inform 2002, 88:38-43.

Publish with Bio Med Central and every scientist can read your work free of charge

"BioMed Central will be the most significant development for disseminating the results of biomedical research in our lifetime. " Sir Paul Nurse, Cancer Research UK

Your research papers will be:

- available free of charge to the entire biomedical community

- peer reviewed and published immediately upon acceptance

- cited in PubMed and archived on PubMed Central

- yours - you keep the copyright

Submit your manuscript here:

http://www.biomedcentral.com/info/publishing_adv.asp 